\title{
Unearthing entrepreneurial opportunities among youth vendors and hawkers: challenges and strategies
}

Isaac Kofi Biney

Correspondence: ibiney@ug.edu.gh; ikkbiney@yahoo.co.uk

University of Ghana, Legon, Accra, Ghana

\begin{abstract}
This paper explores entrepreneurial opportunities among youth engaged in vending and hawking on the streets of Accra, Ghana. It ascertains challenges faced and strategies adopted to address them. Street vending and hawking is assuming increasing dimension due to paucity of formal job opportunities in Ghana. Hawking and vending of newspapers, textbooks, toffees and fruits are informal entrepreneurship opportunities on our streets. The study sought for short to medium and long-term plans the youth have to innovate the entrepreneurial opportunities in trades engaged in. It used youth hawkers operating at Okponglo and Dzorwulu junctions. Fifteen (15) youth participated in the study. It is a qualitative study which adopted purposive and convenience sampling procedures in selecting the sample. Thematic, analytical, descriptive-narrative interpretivist approaches were adopted in presenting the results. Crossing roads, chasing moving vehicles, operating in the scorching sun and torrential rain impacted negatively their health. It also emerged that the youth have plans to innovate and grow businesses, but the high cost of credit is a barrier. Lack of collateral for credits came up. Government quasi-financial institutions and non-bank financial institutions should be proactive in providing financial, advisory and technical support to the youth to exploit entrepreneurial opportunities in Ghana.
\end{abstract}

Keywords: Entrepreneurial opportunities, Youth vendors and hawkers, Innovation, Financial support

\section{Introduction}

The building of youth entrepreneurship mindset is currently receiving some attention in Ghana. This is probably because the public sector is unable to employ many young adults, who are willing to work, but lack job avenues. More so, many industries established in the 1960s in the communities have collapsed. Many energetic, but ambitious young adults are experiencing mass extensive unemployment, and poverty. As a result, many young people have moved from the rural communities to the national capital, Accra, for jobs which are largely non-existent. These difficulties confronting young adults in Ghana are manifesting themselves in increased vigilantism, hooliganism, armed robbery and wanton destruction of fertile arable lands and forest vegetation cover through 'galamsey' activities in our communities. In the midst of these seeming insurmountable difficulties, some of the adventurous young adults have taken to street

(c) The Author(s). 2019 Open Access This article is distributed under the terms of the Creative Commons Attribution 4.0 International License (http://creativecommons.org/licenses/by/4.0/), which permits unrestricted use, distribution, and reproduction in any medium, provided you give appropriate credit to the original author(s) and the source, provide a link to the Creative Commons license, and indicate if changes were made. 
vending and hawking, to make ends meet. They are engaged in one trade or the other, and this should be expected because the youth, according to Ghana Statistical Service (GSS 2017), constitutes about $48 \%$ of Ghana's population. This, perhaps, might have informed the Government of Ghana's policy strategies of 'One-district one-factory' and 'Planting for food and jobs'. Then again, Ghana, to The World Bank (cited in Baafi and Acheampong 2014), needs to create between six to seven million new jobs by 2030 to absorb people entering the world of work. The National Entrepreneurship and Innovation Plan (NEIP) was created to support young enterprising people with credits to fund their enterprises. Does access to credits comes to the youth on time?

Many young informal entrepreneurs operating at Okponglo and Dzorwulu junctions in Accra hawk and vend in assorted products and services, including newspapers, textbooks, toffees, food and fruits. Some of them have only basic education, contrary to Scarborough (2012) observation that 'people with more education are more likely to start businesses than those with little education' (p. 16). The questions to ask are: What are the plans of the youth in the short, medium and long term in their trades? Do the young enterprising people have what it takes to drive businesses successfully? What is the role of education to the youth in managing their trades? These and many questions have to be answered, if the young enterprising informal people are to be successful in their trades. It does require that the young business people are supported to come up with realistic business plans, secure education and training for requisite knowledge and skills in business management. Lack of skills in managing businesses, perhaps, informed Adult Learning Australia to partner Commonwealth Learning, Australia, to design Adult Community Education project to address the needs of small enterprises that fit within small business limitations (Newton 2006). Castrechini (2017) is of the view that developing learning activities to raise awareness and power of students to be competent in innovating is the ultimate goal of contributing to entrepreneurship and self-employability. Thus, designing entrepreneurship education activities similar to Adult Learning Australia for the young enterprising business people in Ghana to develop growth mindset, as observed by Dweck (2008), is an approach to be adopted. This is important because when the young enterprising people become knowledgeable with skills in business management, they would register their businesses, identify sources of funding, keep account and promote their businesses in the short-, medium- to long-term basis through the appropriate media. This study seeks to ascertain the entrepreneurial opportunities of the youth in Ghana. It establishes that the youth can take advantage of entrepreneurial opportunities in Ghana, and build resilient enterprises in the short-, medium- to long-term periods through education. The researcher used vendors and hawkers at Okponglo and Dzorwulu junctions in Accra, engaged in one trade or the other, for this study.

\section{Statement of the problem}

The desire of the youth to go into entrepreneurship seems high in Ghana. Perhaps, the Government of Ghana interest in promoting the private sector, and promote entrepreneurship among the youth, could be a factor. Youth entrepreneurship programmes, including the \$10-million National Entrepreneurship and Innovation Plan (NEIP), National Youth Authority (NYA), Steps towards Employment and Productivity (STEP) and the Informal Youth Enterprise Development Programme (IYED) have been 
introduced. That notwithstanding, there is paucity of job opportunities in Ghana. This situation has compelled the youth to engage in one form of informal trade or the other to make a living. This is a laudable step taken by the youth; after all, the fruits of entrepreneurship include greater employment opportunities, increase in income, higher standard of living, improved communities and better quality of life of individuals. It is perceived that effective innovation of entrepreneurial opportunities will result in not only employment of the budding entrepreneurs but also affect positively economic growth, and generation of employment opportunities. The researcher, therefore, finds it worthwhile an effort to conduct a study to ascertain the short-, medium- and long-term plans the youth have in unearthing entrepreneurial opportunities in Ghana. The favourable business climate prevailing in Ghana could largely empower the youth to take informed decision in investing their investible resources in small enterprises. Provision of appropriate education appears key to the young entrepreneurs to plan and manage their enterprises to achieve their goals in life.

Currently in Ghana, the inflation situation is easing up and interest rate is improving, such that the young entrepreneurs with proper business plans can solicit funds from the banks with lower interest rate to grow their enterprises. The difficulty, however, is that the youth-led informal entrepreneurs are not investing in education to grow their enterprises. They lack financial literacy skills, management skills, business plans and knowledge of registering their businesses. It appears that there are no innovations infused into growing their operations. The young vendors and hawkers continue to run after moving vehicles in scorching sun and torrential rains. These challenges have arisen, probably, as a result of the difficulties observed, and must be addressed. The question then is: What challenges are limiting vendors and hawkers from growing their informal trades in the short-, mediumand long-term basis? It also sought for strategies adopted by the young entrepreneurs to surmount challenges facing them. The researcher next considers objectives undergirding the study.

The main objective of the study is to ascertain from vendors and hawkers entrepreneurial opportunities, challenges and strategies adopted to surmount challenges encountered. On the basis of the major issue raised, the specific objectives of this study are to:

1. Find out the benefits vendors and hawkers derive from informal trades engaged in.

2. Identify perceived challenges impeding vendors and hawkers from exploiting entrepreneurial opportunities in the short-, medium- and long-term basis.

3. Suggest educational programmes in addressing challenges in entrepreneurial activities.

\section{Literature review}

\section{Entrepreneurial opportunities in Ghana}

Youth entrepreneurship is receiving some level of attention in Ghana. The reason, perhaps, is that the public sector is unable to employ the teeming unemployed young adults seeking employment which are largely non-existent. Hawking and vending has 
taking upward turn in Ghana, especially on the major highways in Accra. Entrepreneurial opportunities abound in Ghana; however, many people do not have the entrepreneurial eye to recognise unrecognised needs in communities, and fully exploit them. Entrepreneurs, by virtue of education, training, skills, attitudes and experiences, are able to recognise business opportunities and turn them into successful enterprises. This requires from the young entrepreneurs courage, character and faith. But what exactly is an opportunity as far as enterprise creation is concerned? Barringer and Ireland (2013) assert that 'an opportunity is a favourable set of circumstances that creates a need for a new products, service or business' (p. 69). Studies reveal that most entrepreneurial ventures started in one of two ways. One is externally stimulated, and the other businesses are internally created. Cordeiro (2007) and Barringer and Ireland (2013) assert that an entrepreneur recognises a problem or an opportunity gap and creates a business to fill it. Perhaps the young hawkers and vendors plying their trade at Okponglo and Dzorwulu junctions have identified needs of certain products and services people demand, and willing to procure. They thus built businesses around them. Assorted beverages, newspapers, handkerchiefs, toffees, plantain chips, fruits and books are sold at Okponglo and Dzorwulu junctions; two of the busiest junctions in Accra. The questions to ask include: Are there any benefits and challenges that confront the young entrepreneurs in their trades? Are there any prospects for the young entrepreneurs to build their enterprises in the short, medium and long term basis? If so, what strategies are to be adopted to succeed in the youth entrepreneurial drive?

\section{Benefits of small informal enterprises}

Research reveals that small enterprises bring benefits to the individuals, communities and economies, especially in the developing countries, including Ghana. Entrepreneurs tend to be happier, healthier and less likely to be divorced from their ventures than colleagues who worked for large firms (Murphy 2010). This means that entrepreneurship could be learned. Thus, the provision of appropriate entrepreneurial education would enable the budding business people to evaluate the entrepreneurial opportunity identified. Such entrepreneurs assess the resources required to turn the opportunity into benefits, acquire the needed resources to succeed in their ventures and manage the ventures and then enjoy the fruit of their labour. The economic prospects and growth being experienced in Ghana generates a growing demand for new needs, thus opening up opportunities for creating small ventures, and encourages the development of entrepreneurship. Construction work in Ghana is booming, and so is service industries, including the telecommunication sub-sector, media houses and the banking sector. These organisations are in good business, and the workers go to work early and close from work late. They buy food, newspapers and other items on the way to work making hawking and vending on these two junctions attractive trading posts to the youth. When properly planned, nurtured and supported by government institutions, the informal business people would grow their trades, legally register, licence and subject them to government labour regulations. By so doing, small entrepreneurs would improve not only their quality of life but that of others as well. As observed by Cordeiro (2007), small entrepreneurs are sensitive to the market, and continually innovate and develop new products. That in itself means that small entrepreneurs tend to be efficient in 
producing and delivering goods and services to the market for profit from short-, medium- to long-term basis. Although becoming an astute entrepreneur demands acquisition of certain critical skills set, yet it is more of a process, a belief and commitment. Displaying hard work, passion and creativity would eventually make entrepreneurs grow their ventures to employ many others, retain wealth locally, generate external wealth and distribute income more equally in the communities. As they work hard to formalise their ventures, they would become registered and start paying tolls, stamp duties and taxes to the government. Succeeding in this direction requires education and training, and that is exactly what the vendors and hawkers on our streets require to grow their trades in the short-, medium- and long-term basis. After all, the policies of government include the reduction of cost of borrowing credit, waiving of some nuisance taxes and the reduction of electricity and water tariffs. These strategies are aimed at empowering, particularly small entrepreneurs, to expand their operations to reduce the growing unemployment in Ghana.

\section{Challenges of small informal enterprises}

On challenges budding entrepreneurs encounter in managing their small enterprises seem huge, such that more than $70 \%$ of newly established enterprises, to Cordeiro (2007), tend to collapse in their first year. Even though operators of small informal enterprise have opportunities to develop a range of skills and knowledge in leadership, confidence and self-esteem, many of the youth-led small enterprise operators in Ghana seem to lack adequate education and training. To succeed, and equally become an astute entrepreneur requires continuing education and training, considering the dynamics and fast-pace changes taking place in enterprise management. Small informal enterprises tend to be labour intensive, and are designed to fill niches that have not been effectively serviced, yet it appears the operators' lack the experience, funds and influence needed to establish successful enterprises. Indeed, in certain economies, as Cordeiro (2007) observes, small informal enterprises which involve large numbers of youth are often co-operatively owned, and operated. After all, without employment opportunities, many young people find their talents being wasted, and resort to unhealthy social activities as being witnessed in Ghana, today. More so, the adventurous young informal operators in Ghana appear not to have established for themselves co-operative society, to build savings culture to support their businesses. Indeed, many of the youth-led informal enterprise operators seem to lack financial literacy to grow their enterprises successfully. As observed by Legodi and Kanjere (2015), the majority of people in the informal enterprise do not have skills that are needed in the formal employment sector, others are semi-literate and a small percentage has some level of qualification. In Ghana, many of the operators of the informal enterprises, particularly at Okponglo and Dzorwulu junctions, are found chasing vehicles, standing in the scorching sun and torrential rain at a high cost to their health and life.

\section{Strategies to address challenges facing small informal enterprises}

On strategies to save youth-led small enterprises from being squeezed out from their entrepreneurial capabilities by large enterprises, the operators have to plan for short-, medium- and long-term basis of their enterprises. The reality is that enterprise is 
employment alternative, hence the youth have to be assisted through training, education, guidance, advisory services and programmes to put their ideas into practice. By so doing, they would understand the dynamics of changes in enterprise management, and learn to exploit entrepreneurial opportunities at their disposal, intelligently. This calls on the operators of small enterprises to possess knowledge in market testing, personal experiences and business planning, not only in the short-term basis but also in the medium- to long-term basis. That also requires good educational level and enhanced problem-solving skills. Empowering the youth through education, training and appropriate credit facilities to drive small enterprises is another sure way of integrating and growing the economy of Ghana. When properly executed, more job opportunities would be exploited and created to absorb an ever-increasing youth bulge. Tax revenues would equally go up to make the economy of Ghana become buoyant and thriving. To Ryan (2006), the huge numbers of unemployed young people should be supported by what he describes 'Youth Credit Initiative' and 'Micro Credit Management System.' These initiatives have their variants in Ghana. The Government of Ghana should create supportive climate for entrepreneurs, including ensuring that the quasi-financial institutions provide services such as credit facilities and incentives to budding entrepreneurs. This is critical because helping to raise the self-confidence, commitment and aspirations of young entrepreneurs through financial, advisory and technical support services would aid them even if their enterprise fails. In any event, Gamieldien and Niekerk (2017) have made us understand that despite hardships associated with this vending [and hawking], street vendors adapt to social, political and economic challenges in their context. Young entrepreneurs should develop for themselves strategic thinking skills through learning informally from those who have gone before them, including taking advantage of role-models or mentors, to grow their enterprises. Training operators of youth-led small enterprises to dream dreams and have visions are significant in driving their ventures. The success of a visionary approach, as Kourdi (2015) observes, depends ultimately on pragmatism: the ability to achieve a vision by listening, acting and learning rather than adopting plans or rigid approaches.

\section{Methods}

Vendors and hawkers formed the sampling units and unit of analysis in the design. The study adopted qualitative approach in finding out from youth-led informal entrepreneurs whether they have been planning for their trades in the short to medium and long-term basis. Qualitative design was chosen primarily because the author sought to collect in-depth information from participants on their appreciation of their ventures and how to continuously educate themselves to address challenges they face in business. This is because, as they learn on and off the enterprises, their capacities are built to develop and deepen interest in entrepreneurial opportunities that comes their way. Qualitative research approach was adopted at every stage throughout the study. The aim of the study was not to statistically generalise the findings to populations, but to secure an in-depth meaning and understanding of the subject understudy on the informal ventures they engage themselves in. The author conducted this study to grasp subtle shades of meaning, experiences as the youth undertake their businesses, and for pulling together divergent information and views of 15 informal entrepreneurs on effective ways of building sustainable micro-enterprises for themselves. Purposive and 
convenience sampling procedures were sought in selecting the sample for the study. Purposively, the study was conducted at Okponglo and Dzorwulu junctions where many youth-led informal entrepreneurs, thus, vendors and hawkers, ply their trades. The vendors and hawkers were conveniently available and accessible to the researcher. Indeed, having discussed my intention and content of the study to the potential participants, they expressed their willingness to participate in the study. The fact really is that, in the midst of the busy traffic, commuters and motorists procure assorted products from the young informal entrepreneurs, as they do brisk business.

In-depth interview with 15 vendors and hawkers formed the main source of information for the study. The questions posed to the young informal entrepreneurs were entirely open-ended types. All interviews were informal and conversational in nature, which made it much possible for the researcher to inquire and probe further when participant's response call for follow-up questioning. This approach adopted made it possible for the researcher and participants to co-construct the narrative. This situation or position taken by the researcher and participants helped avoid the ethical problems associated with revealing more than the participants care to have revealed. The questions were grouped into three sections based on the three specific objectives raised. Section $A$ was on benefits vendors and hawkers derive from their trades. The participants were asked some of the following questions: Were there any benefits derived from your trade? If yes, tell me. Would you say the benefits are good to impact positively on you? Section 2 which was on perceived challenges which impede vendors and hawkers from exploiting entrepreneurial opportunities, participants were asked: Do you have plans to explore other entrepreneurial opportunities? What challenges are presently facing you? What challenges are you likely to face between 3 to 5 years as you plan to expand your venture? Section 3 was on education strategies and programmes to address challenges in entrepreneurial activities. Participants were asked the following questions: What educational programmes do you think would help you in your business operation? What institutions should be providing the educational services? And finally, what other programmes and supports would help you take advantage of entrepreneurial opportunities you dream of? Thematic analysis was performed on the data following the steps recommended by Creswell (2012, 2013). The results of the study are presented next.

\section{Results and discussions}

This section is divided into three main sections. The first section finds out, and also discusses, the benefits of small informal trades engaged in by vendors and hawkers. This is followed by perceived challenges vendors and hawkers encounter in exploiting entrepreneurial opportunities in the short-, medium- and long-term basis, and finally, education strategies and other programmes vendors and hawkers could adopt to address challenges facing their entrepreneurial activities.

\section{Benefits vendors and hawkers derive from informal trades}

The study identified varied benefits vendors and hawkers derive from their trades that kept them doing the business. When the participants were asked whether there were 
any benefits from their trades, they admitted in unison that they receive profits from the products and services they offer for sales. The finding confirms Cordeiro (2007) assertion that small entrepreneurs tend to be efficient in producing and delivering goods and services to the market for profit from short-, medium- to long-term basis. The vendors and hawkers added, however, that the profits are not fixed, but varies. It depends on the sales of the day. This is an apt way a participant puts it:

The profit margins we derive from our businesses keep varying. Business is good some days, and in some other days, it tends to be bad.

They added that their ventures afford them the opportunity to keep body and soul together. They further indicated that trades they engage in help them establish broad social networks, build contacts and relationships with notable persons. The revelation by the participants ties in well with observation made by Cordeiro (2007). He indicates that the ultimate goal of enterprise is not earning more money or having a better lifestyle; those are really only motivating strategies. The much more important thing is living a more abundant life, thus more social, more thoughtful, more proactive and more spiritually fulfilling life. The participants admitted that, in the short to medium term, good sales realised in their trades would help them expand and broaden the base of their businesses. When asked whether the benefits derived from their trades were good enough to impact positively on their lives, the participants were in the affirmative. They agreed that when sales for the day are good, they are able to embark on their daily savings. To conceive of embarking upon savings, in itself, speaks volumes. This, to the researcher, indicates that the vendors and hawkers have learned on the jobs they engage in, and it constitutes a sign of progress. Asked whether they find the future bright with the trades engaged in, this is one good way a vendor who dealt in car dash-board spray product expressed it:

I continue to see progress in my daily savings. I have not taken a loan from bank before in doing this business. I have been managing this business with my private savings.

Considering the confidence in which the participant expressed about his performance in the trade he engages in, the researcher cannot help but agree with Lazarus (cited Kanter 2006) that confidence and success are inextricably linked. The participant understands and has purpose in the trade he finds himself. Probed further whether the participants find the trades engaged in sustainable, they responded in unison. They however, added that they cannot stay home doing nothing with their lives. They asserted that, when they remain inactive at home, it would be costly financially and psychologically to them. They added that these small informal ventures they engage themselves in, with little planning, they could manage them and achieve much successes. The finding confirms Cordeiro's (2007) observation that success of one's business may depend on one's business plan. Asked whether they have plans to grow, expand and diversify their business, they responded in the affirmative. This is one apt way a newspaper vendor puts it: 
My plan is to build my capacity and capital base in this business. By so doing, I can add many more news print to my trade. Currently, I deal in two newspapers, that is; Daily Graphic and Daily Guide. It is my hope that I can secure some credit and procures a container to carry out my business there.

The participants admitted that with appropriate financial and technical support from government, and other stakeholders, they would be able to expand their businesses in the medium- to long-term basis.

\section{Challenges facing small informal enterprises}

In terms of challenges that confront the participants in their businesses, the participants indicated that they are faced with huge, and sometimes, deadly challenges. They asserted that if you are not careful, you may be knocked down by an on-coming vehicle, since their business sometimes involve running after a vehicle to effect a change or collect the money of a product bought. The participants at Okponglo junction revealed that a week before the fieldwork, which was 19/01/ 2018, they lost one of their friends, through motor-vehicle accident, which occurred at the spot they ply their trade. They added that due to the hectic nature of the trade as they run after moving vehicles in the scorching sun and torrential rain, they usually fall sick, or are sent down by malaria. They admitted that they sometimes find it difficult treating themselves properly from the ailment due to meagre profit they make out of the trades they engage in. This is one best way a participant who trades in cocoa chocolate puts it:

The money we do business with is small, however, we manage it. Sometimes, when the business is good, we run to our suppliers to give us additional products to sell and then pay them after business.

This observation made by the participant ties in well with Abor and Quartey (2010) revelation that the small-scale businesses in Ghana lack requisite finance or credit to do their businesses. Throughout the interaction with the participants at both Okponglo and Dzorwulu junctions, they kept asserting that the issues lack of funds, motor-vehicle accidents and sicknesses, especially malaria, were frequently revealed by the participant as the major challenges in their trades. Lack of funds or credits for small businesses has been re-echoed by Todaro (1997) and Todaro and Smith (2009). They assert that commercial banks are not structured to handle small loan requirements with no collateral, and are therefore unwilling to finance small enterprises, especially in the informal sector.

\section{Strategies to address challenges facing small informal enterprises}

Following the benefits derived by participants in their trades' vis-à-vis the challenges that face them, require that appropriate strategies instituted to surmount the difficulties encountered. When probed further on the challenges participants are likely to face in a short, medium to long term, thus between 2 and 3 years and measures to address them, the participants intimated that lack of credits or funds is their biggest worry. They believed that embarking upon, and building strong 
savings culture, would help them address their challenges. To spread savings culture, according to Bredin (2018) across your company, encourage your team to adopt money-saving habits. Bredin's observation demonstrates that building the savings culture as, or into a small informal business operation, is critical. This is because vendors and hawkers in our part of the world do not possess the collateral security which the financial institutions usually ask them to produce. Then again, considering the fact that their profit margins are small, and as they embark upon savings, they would build for themselves strong financial muscle and security to rely upon to do business seamlessly.

When asked what educational programmes could help them make progress in their trades, skills such as financial literacy, building of savings culture and acquisition of managerial talents came up of mentioning. This finding is in line with Abor and Quartey (2010) observation that lack of financial support and managerial talents are some of the major problems confronting entrepreneurs in Ghana. The researcher is also of the view that the provision of these critical education and financial skills revealed by the participants would go a long way in empowering them to start and grow their businesses beyond the limit of hawking, street vending, letter writing, knife sharpening, junk collecting to selling of dog chains. This is because the banks could use their savings as collateral, and then grant them loans, sometimes in the form of group loans, to expand their trades or informal businesses. After all, Callahan (cited in Drucker 2009) asserts that the company has to expand to give people promotional opportunities. I find this assertion significant to the extent that not until vendors and hawkers grow and expand their businesses, they cannot make any meaningful niche and impact in their market that they serve.

On what institutions should be providing such educational programmes to the young informal entrepreneurs, the participants indicated that they are willing to work with government institutions to build their managerial capacities, granted that they would be supported financially after training, to enable them to expand their businesses in the medium to long term. Institutions which came up of mentioning include National Entrepreneurship and Innovation Plan (NEIP), National Board for Small-Scale Industries (NBSSI) and Macro-Finance and Small Loan Centre (MASLOC) to provide them financial, advisory and technical supports to grow their trades. The three governmental institutions mentioned are significant because they are involved in financing, training and granting of small to medium loans to the youth. To Depatem (2018), a young entrepreneur of 18 years won GHC $75,000.00$, an equivalent US $\$ 15,625.00$ for emerging as a winner of the maiden 'Presidential Pitch' competition, based on cutting-edge and innovative ideas and answers the budding entrepreneur provided in a context in Ghana. That, itself, reveals that the young informal entrepreneurs in Ghana have creative ideas, and what they need is the requisite funding, to get them put into action their laudable and creative ideas. When asked what other programmes and supports the participants think would help them take advantage of entrepreneurial opportunities they dream of in the long term, the participants sought for reliable soft loans and continuous advisory services to aid them expand and grow their trades. One of the participants aptly expressed it in this way: 
Governmental and quasi-governmental institutions, financial institutions, and the private sector players should come on board and support us in our trades.

\section{Conclusions and recommendations}

The paper explored operations of vendors and hawkers at Okponglo and Dzorwulu junctions in Accra, Ghana. The challenges the young informal entrepreneurs encounter, and the strategies adopted to surmount them, were also looked at. As an exploratory study, the findings made cannot be generalised. It is the firm conviction of the researcher that quantitative study is conducted to validate the findings made. The researcher, who is a lecturer and coordinator of Accra Learning Centre, School of Continuing and Distance Education (SCDE), University of Ghana, uses both Okponglo and Dzorwulu junctions to workplace at the Accra Learning Centre. He has been observing the operations and activities of the vendors and hawkers as they undertake their businesses, hence this important and insightful study. Considering the enormous challenges confronting today's youth, especially the problems of unemployment and poverty, thus make it necessary that conscious effort is made by governments, training organisations and financial institutions to provide diverse, but workable strategies to support the youth to grow their informal trades. Although laudable the 'One district, one factory' and 'Planting for food and jobs' policies of the government, the researcher is of the view that not all the youth in Ghana are interested to go into agriculture. More so, not all the youth would be absorbed by the factories when made operational. It thus becomes important that the young informal entrepreneurs who have ventured into trades to make ends meet are supported to grow and drive their entrepreneurial endeavours. By so doing, they would learn to surmount many of the challenges, including avoidable ailments, lack of credits, financial literacy skills and lack of managerial talents that confronts them in their entrepreneurial endeavours. This is significant, because as observed by Drucker (1993), entrepreneurial economy will [not] primarily remain that of an American phenomenon, and industrially developed countries, but that of [developing economies, including Ghana]. Commenting on South African situation of informal traders, Arenius et al. (2005, cited in Fundie et al., 2015) assert that informal traders have attracted increasing attention in recent years in light of concrete evidence of the importance of new business creation for economic growth and development. On the basis of these assertions, the researcher is of the view that every necessary support is to be provided to the youth into vending and hawking in Ghana, to make massive headway in their entrepreneurial drive.

In order to maximise profits from informal enterprises engaged by vendors and hawkers, it is recommended that, in the short term, the vendors and hawkers:

- Should remain honest, sincere and trustworthy to their wholesalers who do business with them, such that they would reliably receive whatever quantities of products they vend and hawk.

- Should, by demonstrating hard working capabilities in their trades, also build for themselves confidence and the 'can-do' spirit, such that they would not give up so easily to what they have decided to do. 
In order to avoid many of the challenges vendors and hawkers face in their day-to-day activities, it is recommended that the informal entrepreneurs:

- Should be extra careful even as they cross the roads to sell their products. Risky plays on the road should be avoided.

- Should go to ply their trade early in the morning to avoid vending and hawking in the scorching sun and torrential rains. By so doing, they would escape from ailments, coupled with attendant financial expenses they could not bear.

It order to surmount many of the challenges vendors and hawkers face in their day-to-day operations, it is recommended that government agencies, including NBSSI, NEIP and MASLOC:

- Should regularly organise and provide education, training and advisory services to the youth on informal entrepreneurship. In so doing, the youth would comprehend the management and leadership skills required to succeed in such ventures. Proper provision of such services would enable the youth gain further insight into their trades, and thus enter into partnerships, and also give new lease of life to their ventures.

- Should continuously offer soft loans in the form of group lending, with flexible payment terms, to the youth. By so doing, repayment could be guaranteed by the group, to keep the youth firmly in their business operations.

Considering the findings and recommendations made, I suggest that further research could be conducted to validate some of the findings of the study. It is my hope, as a researcher, that a field study is designed to unpack motivational strategies which encourage the youth to become self-employed in the rural communities of Ghana. When this study is supported and the findings judiciously applied, it would help reduce the seemingly uncontrollable and uncoordinated internal migration of the youth from the regions to the national capital, Accra, for non-existent jobs. The researcher therefore concludes by stating that Ghana's entrepreneurship policy, which is currently being developed, is expedited to give full meaning to the field of entrepreneurship, and its significance to national development. Every effort should also be made by key stakeholders, in youth entrepreneurship, in devising strategies to reintegrate the young vendors and hawkers into the mainstream business environment. This is because their sheer numbers, which keeps increasing by the day, makes their operations appear chaotic at major junctions of the roads, particularly in Accra. Indeed, the youth in the rural Ghana are to be supported to create jobs for themselves, so as to make their respective communities more vibrant and sustainable.

Acknowledgements

The author thanks the participants for first consenting, and actually participating in the study. I, again, thank my colleagues at Accra Learning Centre, for working hard at the assigned tasks and responsibilities at the Centre, as far as their work is concerned, such that I could make time enough time to undertake academic research to extend the frontiers of knowledge. 


\section{Availability of data and materials}

An In-depth interview guide was designed under the heading, 'Unearthing Entrepreneurial Opportunities among Youth Vendors and Hawkers: Challenges and Strategies', to collect data from the participants for the study. The said instrument is attached on a separate document.

\section{Author's contribution}

The author designed, planned and put the paper or article together. The author read and approved the final manuscript.

\section{Author's information}

Dr. Isaac Kofi Biney is a lecturer at School of Continuing and Distance Education (SCDE), College of Education, University of Ghana, Legon. He lectures at the Department of Adult Education and Human Resource Studies a number of courses at diploma, undergraduate and graduate levels, including Theories of Adult Learning, Community Development and Entrepreneurship. He is the Coordinator of Accra Learning Centre of SCDE. Dr. Biney received his B.Ed. (Foundations) degree (1999) from University of Cape Coast, his M.Phil. (Adult Education) degree (2003) and Ph.D (Adult Education) degree (2009) from University of Ghana, Legon. Dr. Biney also holds a certificate in Social Mobilisation for Health and Development (2008) from School of Public Health, University of Ghana, Legon. His research interests are in Adult Learning, Community Development and Entrepreneurship. 'Teacher Motivation and Learner's Interest: Perspectives of an Adult Educator' is Dr. Biney's first book. He also has over twenty (25) articles and book chapters to his credit. Some of the learned academic journals Dr. Biney has published in include PAACE Journal of Lifelong Learning, Journal of Studies in Education, MIER Journal of Educational Studies, Trends and Practices (MJESTP), Journal of Community Development Practice, International Community Development Journal, Journal of Education, Development and Innovation (JEDI), GIMPA Journal of Leadership, Management and Administration, Tertiary Education Series, and International Journal of Lifelong Education. Dr. Biney has presented over 40 papers in international conferences and seminars.

\section{Competing interests}

The interest of the researcher for conducting this study is to inform policy direction on the need to develop entrepreneurship policy to really capture the entrepreneurial needs, plans, interest, development and supports for the youth, to create jobs for themselves since the formal sector of the economy is unable to employ them.

\section{Publisher's Note}

Springer Nature remains neutral with regard to jurisdictional claims in published maps and institutional affiliations.

Received: 29 June 2018 Accepted: 17 December 2018

Published online: 11 January 2019

\section{References}

Abor, J., \& Quartey, P. (2010). Issues in SME development in Ghana and South Africa. International Research Journal of Finance and Economics. Issue, 39(2010), 218-228.

Baafi, A. A., \& Acheampong, J. (2014). Ghana needs 7 million jobs by 2030—World Bank. Daily Graphic. p. 69.

Barringer, B. R., \& Ireland, R. D. (2013). Entrepreneurship: successfully launching new ventures (4th ed.). Boston, MA: Pearson Education Limited.

Bredin, A. (2018). Creative ways to build a culture of savings. Accessed 27 June 2018 from https://www.pge.com/en/ mybusiness/save/smbblog/article/creative-ways-to-build-a-culture- of-savings.page.

Castrechini, A. (2017). How to educate "for" entrepreneurship? A teaching innovation project address to future psychologists. Proceedings of EDULEAN17 Conference, 3rd-5th July, 2017, Barcelona, Spain. https://doi.org/10.21125/ edulearn.2017.0843.

Cordeiro, S. (2007). Promoting enterprise and economic development. London: Commonwealth Secretariat.

Creswell, J. W. (2012). Educational research: Planning, conducting, and evaluating quantitative and qualitative research (4th ed.). Boston, MA: Pearson Education, Inc..

Creswell, J. W. (2013). Research design: qualitative, quantitative, and mixed methods approaches (4th ed.). Thousand Oaks, CA: Sage Publications, Inc

Depatem, D. A. (2018). Entrepreneur, 18 gets GHC75,000.00: She wins maiden Presidential Pitch. Daily Graphic. p. 16.

Drucker, P. K. (1993). Innovation and entrepreneurship: practice and principles. New York: Harper.

Drucker, P. F. (2009). Management cases: Revised edition. New York: Collins Business.

Dweck, C. S. (2008). Mindset: the new psychology of success. New York: Ballantine Books.

Fundie, A. S., Chisoro, C., \& Karodia, A. M. (2015). The challenges facing informal traders in Hilbrow area of Johannesburg. Kuwait Chapter of Arabian Journal of Business and Management, 4(6), 46-75.

Gamieldien, F., \& Niekerk, L. V. (2017). Street vending in South Africa: an entrepreneurial occupation. South African Journal of Occupational Therapy, 47(1), 24-29.

GSS. (2017). Small and micro-sized businesses engage more workforce- survey. Accra: Ghana Statistical Service.

Kanter, R. M. (2006). Confidence: how winning streaks and losing streaks begin and end. New York: Three Rivers Press.

Kourdi, J. (2015). Business strategy: A guide to effective decision-making (3rd ed.). New York: Public Affairs, The Economist.

Legodi, K., \& Kanjere, M. (2015). Challenges faced by informal traders in Greater Letaba municipality in Limpopo province. Africa's Public Service Delivery and Performance Review, 3(4), 57-75.

Murphy, B. (2010). The intelligent entrepreneur: How three Harvard Business School graduates learned the 10 rules of successful business. London: Virgin Books.

Newton, K. (2006). Small business and human capital: the role of adult community education. Sydney: Commonwealth Learning of Australia. 
Ryan, C. (2006). Youth enterprise and sustainable development' strategic paper for the $6^{\text {th }}$ commonwealth youth ministers' meeting. London: Commonwealth Secretariat.

Scarborough, N. M. (2012). Effective small business management: an entrepreneurial approach (10th ed.). Boston, MA: Prentice Hall.

Todaro, M. P. (1997). Economic development. New York, NY: Longman.

Todaro, M. P., \& Smith, S. C. (2009). Economic development (10th ed.). New York: Pearson.

Submit your manuscript to a SpringerOpen ${ }^{\circ}$ journal and benefit from:

- Convenient online submission

- Rigorous peer review

- Open access: articles freely available online

- High visibility within the field

- Retaining the copyright to your article

Submit your next manuscript at $\boldsymbol{\nabla}$ springeropen.com 